\title{
Linguagem no Discurso de Roma: Programa de Leitura da Psicanálise ${ }^{1}$
}

\author{
Léa Silveira Sales ${ }^{2}$ \\ Universidade Federal de São Carlos
}

\begin{abstract}
RESUMO - O mais característico programa lacaniano de leitura da psicanálise - aquele que conclama retornar a Freud - é paradigmaticamente anunciado em 1953 no Discurso de Roma. Nessa conferência capital, a psicanálise é submetida a uma "tradução" baseada em instrumentais bastante específicos, notadamente, nos que provêm das filosofias de Kojève e de Heidegger e da antropologia de Lévi-Strauss. Com uma análise interna desse texto, buscaremos acompanhar alguns componentes desse programa - especialmente os que se relacionam aos temas da oposição fala vazia/fala plena, da intersubjetividade e da ordem simbólica - com o intuito de promover uma aproximação de seu sentido.
\end{abstract}

Palavras-chave: epistemologia da psicanálise; psicanálise lacaniana; linguagem; fala.

\section{Language in the Rome Discourse: Program to Read Psychoanalysis}

\begin{abstract}
The most characteristic lacanian program of reading psychoanalysis - the one which claims a return to Freud - is paradigmatically announced in 1953 in the Rome Discourse. In this capital conference, psychoanalysis is submitted to a "translation" based on very specific instruments, mainly those which come from Kojève's and Heidegger's philosophies and from Lévi-Strauss's anthropology. With an internal analysis of this text, we will try to follow some components of this program - specially those related to the opposition empty speech/full speech, the intersubjectivity and the symbolic order - with the purpose of promoting an approaching to its meaning.
\end{abstract}

Key words: epistemology of psychoanalysis; Lacanian psychoanalysis; language; speech.

Função e campo da fala e da linguagem em psicanálise é o título de um relatório produzido por Lacan, em 1953 , e que é mais comumente conhecido como o Discurso de Roma $^{3}$. Texto considerado programático - pois defende a tese característica ao pensamento lacaniano da década de 50 - seu tom polêmico deve-se a uma circunstância histórica específica cuja explicitação o autor se dedica no prefácio: trata-se, para ele, de se opor radicalmente tanto à teoria quanto à técnica da doutrina clássica, abrindo um novo horizonte de inteligibilidade para a psicanálise. É o próprio Lacan quem confirma a importância da referência ao contexto: "O discurso que encontraremos aqui merece ser introduzido por suas circunstâncias. Pois ele traz delas a marca." (1953b/1966, p. 237).

Tal pronunciamento fora programado para ocorrer em setembro de 1953 na XVI Conferência dos Psicanalistas de Línguas Romanas. Lacan havia sido convidado, por ser o presidente da instituição, a apresentar o relatório teórico da Sociedade Psicanalítica de Paris (SPP) neste congresso. Porém, entre a data do convite e a ocasião do congresso, produziu-se uma secessão na SPP com a conseqüente renúncia

1 Este artigo resulta da dissertação de mestrado "Dos complexos familiares ao Discurso de Roma: Lacan rumo à racionalidade estruturalista", defendida na Universidade Federal de São Carlos, orientada pelo Prof. Richard Theisen Simanke e financiada pela CAPES.

2 Endereço: Rua Rafael de Abreu Sampaio Vidal, 2729, ap. 64 Tijuco Preto, São Carlos, SP, Brasil 13566-220. E-mail: lea_silveira@uol.com.br

3 Doravante, referido apenas como Discurso no presente trabalho. forçada de Lacan à presidência e a fundação da Sociedade Francesa de Psicanálise (SFP). Os motivos da dissidência giravam em torno de dois principais pontos, ambos relacionados a divergências teóricas: a falta de ortodoxia do estilo de Lacan na efetuação de seus tratamentos e a rigidez do programa do então nascente instituto de psicanálise responsável pela formação dos futuros psicanalistas. Esse instituto era encabeçado por Sacha Nacht que escolhera para epígrafe de seus estatutos - e, portanto, como lema do instituto - uma citação que indicava que a existência da psicanálise era apenas a expressão de um ramo da neurobiologia. É o mesmo trecho que Lacan, por sua vez, cita com desdém e ironia como epígrafe de seu prefácio. De certa forma, como indica Macey (1988), as propostas formuladas no Discurso constituem uma resposta, em contraponto, ao direcionamento conferido por Nacht à formação dos psicanalistas e, por conseguinte, à psicanálise como um todo.

O público destinatário do Discurso era em sua maioria composto daqueles que apoiavam o movimento separatista encabeçado por Daniel Lagache, que reconheciam em Lacan um dos líderes desse movimento e para quem ele poderia expor livremente tanto a revolta e a contundência de suas teses contrapostas à ortodoxia da SPP, quanto a diferença marcante de seu estilo. Por isso, esse texto foi considerado a magna-carta desse importante capítulo da história das instituições psicanalíticas francesas.

Quanto à técnica de Lacan, ela se recusava a se submeter às normas ipeístas - especialmente àquela relativa à duração das sessões estipulada necessariamente em torno de 50 
minutos - inaugurando assim as famosas "sessões curtas". A insistência nesse tipo de prática, acompanhada da defesa teórica da duração variável da sessão - cujos primórdios se localizam no texto sobre o tempo de 1945 -, foi o estopim de seu posterior afastamento decisivo da IPA no início da década de 60, quando se desfez a SFP e o lacanismo encontrou enfim seu lugar como vertente psicanalítica específica, em sua doutrina e em sua técnica, que não mais procuraria o reconhecimento da instituição fundada por Freud.

Antes de aparecer nos Escritos, o texto fora publicado no primeiro volume de La psychanalyse, de 1956, revista fundada pela SFP após a referida dissensão. Entre os dois períodos, Lacan submeteu o texto a pequenas revisões, algumas das quais consistiram, segundo Wilden (1968), em amenizar um pouco a entusiástica acolhida dispensada à antropologia estrutural de Lévi-Strauss em 1953 e em 1956. Vale lembrar que a segunda metade da década de 60 corresponde justamente à fase inicial do declínio do paradigma estruturalista, durante a qual diversos desdobramentos do pensamento francês propunham uma reflexão em torno de críticas, fissuras e revisões daquilo que outrora ganhara a adesão de alguns de seus grandes expoentes. Uma volta histórica começou a indicar novas cores para o pensamento e muitas daquelas que tinham sido personagens estruturalistas emblemáticas, sentiram necessidade de recusar essa procedência. No Discurso, mesmo tendo ele sofrido essas alterações, a aproximação com o estruturalismo revela seu programa teórico e semeia uma reflexão sobre a clínica, destacando o papel exercido pela linguagem, segundo concepções afinadas com a lingüística e com a antropologia estruturais.

É claro que os diálogos teóricos de Lacan são multifacetados e que é possível encontrar nesse texto uma rica explosão de referências - sem contar seu débito para com todo o percurso anterior do psicanalista. Contudo, todos esses aspectos, ao marcarem presença nesse momento, o fazem desfilando em torno de uma tese central pela primeira vez defendida e desdobrada em suas consequiências para os campos teórico, epistemológico e prático da psicanálise, tese que tem sua condição de possibilidade no encontro com a racionalidade estruturalista, em geral, e com o pensamento lévi-straussiano, em particular, e que conhecerá um caminho inovador e insuspeitado a partir dessa data. O objetivo do Discurso é claro: uma defesa original de que a justa compreensão do empreendimento freudiano só pode ser alcançada quando se reconhece a centralidade efetiva da linguagem. Isso deve ocorrer a partir de quatro pontos interconectados que compõem o alicerce da promulgação de um "retorno a Freud" e que conduzem à tese de que o campo da psicanálise se identifica com o campo da linguagem. São eles: 1) a linguagem é o elemento da experiência psicanalítica; 2) a linguagem é o material constituinte do homem; 3) o inconsciente é a própria estrutura da linguagem, o texto desconhecido que determina a subjetividade para além da consciência, isto é, o inconsciente é o "discurso do outro"; 4) a psicanálise, ao estabelecer seu parentesco com o paradigma científico inaugurado pela lingüística estrutural, vê assegurado para si um lugar legítimo no rigor da ciência moderna.

Todavia, a apropriação lacaniana do estruturalismo continua a revelar no Discurso seu sentido bastante peculiar, pois aí, os aspectos apresentados acima vêm acompanhados da necessidade de se conferir um destaque especial não apenas ao sujeito e à dialética - como já ocorria, por exemplo, em O mito individual do neurótico (Lacan, 1953a/1978- como também à dimensão histórica envolvida no fenômeno em questão. Os dois primeiros temas indicam a permanência da influência de Alexandre Kojève e o terceiro aparece filtrado pelo pensamento de Heidegger. A partir disso, o essencial do Discurso pode então ser formulado em outras palavras: a estrutura da linguagem, sendo o próprio inconsciente, se articula na fala do sujeito que, em sua historicidade e finitude, entra, com o psicanalista, num processo de troca dialética que se direciona para a verdade de seu desejo.

\section{Crítica como introdução}

Todo o texto de Lacan volta-se para um exercício de persuasão em torno da defesa da idéia de que o inconsciente deve ser definido por remissão à linguagem. Com ela, Lacan pretende denunciar a desordem presente na psicanálise que lhe era contemporânea, apresentando a alternativa que favoreceria a correção de seus rumos em dois sentidos concomitantes: seu encaminhamento científico e sua fidelidade ao sentido dos conceitos freudianos, os quais, ao mesmo tempo, devem ter seu valor histórico original recuperado e que “(...) só podem esclarecer-se ao estabelecermos sua equivalência com a linguagem atual da antropologia ou com os últimos problemas da filosofia, com os quais, muitas vezes, a psicanálise só tem a se beneficiar." (Lacan, 1953b/1966, p. 240). Para Lacan, retomar os verdadeiros fundamentos desses conceitos e enxergar seu sentido original significa, então, lê-los a partir de instrumentos contemporâneos.

A crítica à instituição psicanalítica funciona preparando a formulação do "retorno a Freud"; é preciso mostrar o quanto ela evita reconhecer no campo da linguagem e na função da fala, os fundamentos de sua disciplina. Para Lacan, essa aversão foi o que afinal motivou mudanças de objetivo e de técnica relacionadas com o amortecimento da eficácia terapêutica. A análise dos estudos psicanalíticos existentes revelaria, ao lado de sua ineficiência, o quanto eles estariam longe de perceber a verdade da psicanálise, pois esta, só pode ser encontrada num "(...) retorno ao estudo, no qual o psicanalista deveria tornar-se senhor, das funções da fala." (Lacan, 1953b/1966, p. 244). Assim é que se teria tornado impossibilitada a compreensão do sentido da obra freudiana, sentido que fora substituído, a seu ver, por uma técnica enfadonha, opaca e arredia a qualquer crítica, padecendo de um excesso de formalismo estéril. A psicanálise depois de Freud produziu encaminhamentos teóricos que tendem a desconhecer a verdadeira estrutura da análise, que é uma estrutura dialética ${ }^{4}$. A tendência conhecida como "análise das resistências", por exemplo, afasta-se essencialmente de um conhecimento do sujeito porque não tem como princípio a intersubjetividade da fala. Tende a se eternizar no registro do imaginário e, portanto, a promover uma objetivação sempre maior do sujeito.

Lacan destaca em sua crítica a situação do grupo norteamericano, então hegemônico: suas características - cujo

4 Cf. a leitura do processo analítico como desdobramento dialético que Lacan realiza em Intervenção sobre a transferência (1951). 
parentesco com um meio cultural ligado ao anti-historicismo e ao mercantilismo e com uma psicologia dominada pelo behaviorismo teria engendrado uma concepção da psicanálise como instrumento para a adaptação do indivíduo ao meio social e para a busca de padrões de conduta e de objetivação do sujeito - teriam contribuído de modo especial para a obliteração da inspiração de Freud sintomatizada pela ofuscação dos seus termos mais fecundos que são o inconsciente e a sexualidade. Resultaria que o comum entre os psicanalistas formados nesse contexto seria o fato de se encontrarem presos a convenções técnicas e ignorantes com relação à doutrina.

Urgente era, em consequiência, a tarefa de ler Freud. Com a ressalva de que o sucesso desse empreendimento estaria necessariamente atrelado a que essa leitura fosse realizada através de um prisma específico:

(...) a técnica não pode ser compreendida, nem, portanto, corretamente aplicada, se desconhecermos os conceitos que a fundamentam. Nossa tarefa será demonstrar que esses conceitos só adquirem seu sentido pleno ao se orientarem num campo de linguagem, ao se ordenarem com a função da fala. (Lacan, 1953b/1966, p. 246).

\section{Fala}

É de fato inconteste a presença da influência de Saussure no Discurso. Não poderia mesmo ser de outro modo visto que, aqui, Lacan dá continuidade à sua aproximação com o estruturalismo e as raízes dessa forma de pensamento estão fortemente atreladas a esse nome. Todavia, essa afirmação, ao que tudo indica, mais ganharia em consistência se nuançada, pois, por um lado, o acesso de Lacan a Saussure é filtrado por Jakobson e principalmente por Lévi-Strauss e, por outro, se é mesmo possível indicar a existência de uma filiação da psicanálise lacaniana à lingüística saussuriana, é preciso lembrar que seus termos e concepções já aparecem nas linhas de nosso autor tendo recebido a impressão de sua marca, ou seja, tendo sofrido alterações e sido submetidos a acréscimos a partir da grade de conceitos e da racionalidade que possui o seu próprio pensamento. Macey (1988) explica que Lacan não restringe a construção de seu argumento a uma teoria lingüística específica e que o conceito de símbolo, ora central, não se apresenta como algo pertencente a esse campo. Sofrendo os efeitos do encontro com Kojève, símbolo significa pacto ou reconhecimento, como indica a referência à figura da téssera"; o fato de "símbolo" derivar de "sumbolon" - a palavra grega para téssera - é requisitado para funcionar como garantia da justeza da dedução. Coexistem no Discurso, segundo Macey, elementos oriundos da matriz saussuriana e a referência implícita a Jakobson - influências mais aparentadas com o estruturalismo e, portanto com a prevalência da perspectiva sincrônica - com a reverberação

5 De acordo com Wilden (1968), a téssera é uma peça que funciona como senha ou sinal de reconhecimento. Era empregada, por exemplo, em algumas antigas religiões nas quais “(...) juntar novamente as duas metades de um pedaço de cerâmica quebrada funcionava como meio de reconhecimento entre os iniciados (...).” (Wilden, 1968, p. 101). Trata-se de uma figura que resume essa idéia, preciosa para Lacan, de símbolo como laço e reconhecimento. da gramática de Damourette e Pichon - baseada, na contracorrente, em princípios histórico-filológicos - e ainda com explorações etimológicas "selvagens"6.

Para Macey (1988), o esforço de Lacan está mais ligado à geração de uma fascinação amplificada pela linguagem que inclusive culmina numa filosofia que a toma pela essência do ser em um movimento que chega a confundir os níveis de análise. Conforme propõe esse autor, Lacan transita sem muitas hesitações e indiscriminadamente entre a descrição do papel da linguagem no diálogo terapêutico, uma teoria da intersubjetividade humana e uma descrição universalista da linguagem tomada como objeto filosófico puro.

Um dos desdobramentos que a lingüística sofre no Discurso é que Lacan estabelece uma oposição entre fala (parole) e linguagem (langage) diferente da oposição de Saussure que era entre fala e língua (langue). De um modo geral, para Saussure, a linguagem é constituída pela dicotomia dialética entre língua e fala, pela tensão entre um objeto social e um ato individual. Enquanto a língua significa o conjunto das convenções envolvidas na comunicação, sejam elas regras, elementos fonéticos ou valores - uma espécie de contrato coletivo - a fala é o ato de seleção, combinação e atualização desses componentes (Barthes, 1964/1993). Diferentemente, para Lacan, a tensão que existe é entre fala e linguagem. Desnecessário lembrar que sua preocupação não é mesmo o fato lingüístico. A existência de um objeto sistemático, tal como uma língua particular, não atrai seu interesse na medida em que o que está em jogo é uma redescrição da psicanálise. Para tanto, o que lhe é pertinente é considerar o fato mais abstrato de que possa haver signos, símbolos ou significantes. Ou seja, trata-se de pensar, a exemplo de Lévi-Strauss, a ordem simbólica e não uma língua concreta particular. Assim, a linguagem é o veículo da comunicação e o campo em que se define o inconsciente e toda a psicanálise. Mas também é o "muro da linguagem" que opõe resistência à liberação da fala que reside transmutada no sintoma. É pensada, portanto, a existência de uma tensão entre fala e linguagem; esta sempre se opondo à plena realização da fala verdadeira.

Entre os paradoxos que Lacan denuncia existirem na psicanálise, por referência à relação entre fala e linguagem, encontra-se um que talvez possa ser apontado como o paradoxo central de sua própria teoria. Ele é pensado como um traço da civilização científica que se manifesta de pronto na experiência analítica. Trata-se da radical alienação vivida pelo sujeito na modernidade: nas objetivações do discurso, ele perde seu sentido; encontra na ciência o álibi para se esquecer de sua própria condição. Quanto mais se aproxima do conhecimento científico, mais o sujeito se distancia de sua própria verdade. A doutrina psicanalítica, por exemplo, fornece com suas produções teóricas míticas, tais como os conceitos de ego, id e superego, mais uma ocasião para a alienação do sujeito, contribuindo para a espessura do muro de linguagem que opõe resistência à liberação da fala plena.

6 Sobre o recurso à etimologia, Macey observa que ela é explorada por Lacan como um dispositivo meramente retórico e sem rigor. Após comentar diversos exemplos, esse autor diz que, no Discurso e em vários outros textos de Lacan, uma “(...) suposta etimologia mascara uma proliferação de trocadilhos.” (1988, p. 140). 
Na linguagem, o homem está tão alienado quanto o louco em seu delírio. Lacan cita o ensinamento de Pascal: "os homens são tão necessariamente loucos que seria ser louco por uma outra forma de loucura não ser louco." (conforme citado por Lacan, 1953b/1966, p. 283). Dito de outra forma, o paradoxo é que, não obstante, o discurso tenda a objetificar o sujeito, e a linguagem a engrossar cada vez mais sua função de barreira, é pelo discurso e com a linguagem que a análise vai almejar instaurar no sujeito uma fala verdadeira. Ora, mas esse parece ser o mesmo paradoxo que existe no movimento do próprio pensamento de Lacan e aquele risco que ele denunciava na doutrina psicanalítica talvez não lhe seja menos estranho. Pois, da mesma forma, existe de sua parte a tentativa de construir uma ciência do sujeito. Este perde sua condição quando objetivado num discurso científico. Eis o grande problema relacionado a essa noção que envolve o projeto teórico de Lacan e que atinge o clímax de seu caráter paradoxal quando esse projeto se filia à racionalidade estruturalista, pois, a partir dela, o sujeito é dito como algo totalmente determinado pelo poder do significante.

\section{Fala vazia versus fala plena}

Lacan reconhece a existência de dois tipos de fala na análise e encontrou na distinção que traça a filosofia de Heidegger entre Rede (discurso) e Gerede (conversa, fala), os subsídios para nomeá-los "fala plena" e "fala vazia" (Evans, 1996; Macey, 1988 e Wilden, 1968). Segundo Wilden (1968), em Heidegger, Gerede, ao contrário da fala vazia em Lacan, não possui sentido pejorativo: significa um "discurso que perdeu sua relação-de-Ser primária para com o existente sobre o qual se fala, ou então que nunca alcançou tal relação." (Heidegger, conforme citado em Wilden, 1968, p. 201). Aí, a palavra assume o lugar da coisa e a comunicação possui a forma da tagarelice, da "conversa fiada", não permitindo que o existente seja designado em um sentido primordial. Gerede é um fenômeno positivo porque constitui o modo de compreensão e de interpretação do Dasein, muito embora não promova, segundo Macey (1988), nenhuma interpretação real do Ser e indique a separação do sujeito de seu modo primordial de "ser no mundo". Dessa maneira, sua positividade é bastante restrita. Somente Rede é capaz de apreender verdadeiramente o Ser e essa apreensão só pode ser efetivada na relação com o outro. Em Lacan, isso se reflete na importância da intersubjetividade como elemento essencial do encontro analítico, inclusive se a resposta que o sujeito recebe é o silêncio do analista, pois o primeiro apelo que lhe é direcionado é que ele simplesmente seja testemunha de uma fala fundando a dimensão do diálogo. Heidegger, aliás, destaca ser o silêncio "uma possibilidade essencial do discurso" (conforme citado em Macey, 1988, p. 148) capaz de instaurar o discurso e abolir Gerede. Lacan traduz, então, Rede para o campo psicanalítico: "A fala plena é a que visa, que forma a verdade tal como ela se estabelece no reconhecimento de um pelo outro. A fala plena é fala que faz ato." (1953-1954/1975, p. 125/6). Ou seja, a fala plena estabelece o reconhecimento dialético do sujeito pelo analista. Também recebe a alcunha de "verdadeira" pois justamente constitui o tipo de discurso mais próximo da verdade do desejo do sujeito. Nesse período da obra de Lacan, a liberação da fala plena - dito de outro modo, a cumplicidade entre a realização, pelo próprio sujeito, de sua história, o anúncio da verdade do desejo e o reconhecimento desse desejo pelo outro - é, portanto, o objetivo de uma análise.

Para Lacan, as primeiras manifestações do paciente são dominadas por seu narcisismo e se exprimem em tentativas de seduzir o analista. Essa que é a fala vazia habita o registro imaginário e, por conseguinte, diz respeito ao eu e ao processo de identificação no qual o sujeito se perde na linguagem como objeto. Funciona como obstáculo ao estabelecimento da transferência positiva, emperrando a engrenagem do processo analítico. Esse momento de monólogo introspectivo deve ser ultrapassado pelo empenho no trabalho da associação livre.

Por mais que seja algo a ser ultrapassado na direção da fala plena, a fala vazia é a única coisa de que o analista pode dispor para, subvertendo-a, alcançar a verdade do desejo. Não há como deixar de passar pela estrutura imaginária do eu. O discurso, mesmo quando mais se aproxima da verdade subjetiva, mesmo quando se trata da fala plena, é sempre filtrado pelo registro imaginário do narcisismo.

A fala plena, objetivo - pelo que foi dito acima utópico, assintótico - da análise, é caracterizada pela função da anamnese, da referência à história do sujeito tal como relatada no contexto da intersubjetividade. O sujeito deve ser posto diante das intimações dessa fala. Ela é o solo para a interpretação simbólica cujo objetivo é a desalienação do sujeito e cujo ponto de partida é o sentido de seu discurso. Sua atividade se restringe a conferir uma pontuação dialética a essa fala plena que se produz na verdade histórica do sujeito, servindo-lhe de eco, pois essa fala já contém em si a sua própria resposta. A história, afirma Lacan, possui valor de índice e mola do progresso terapêutico. Quando se valoriza a interpretação simbólica da história do sujeito, ao invés da análise das resistências e do hic et nunc, começa a realização da fala plena.

Essas construções teóricas, tão valorizadas nesse momento, passam, no entanto, paulatinamente para segundo plano na obra de Lacan. Macey (1988) considera não terem elas sido elemento estrutural dessa obra visto terem gradualmente desaparecido dos outros écrits; ou melhor, o que teria desaparecido seria a oposição entre fala vazia e fala plena, pois Lacan ainda teria recorrido bastante a esta última isoladamente, especialmente na forma de parole vraie [fala verdadeira] ${ }^{7}$. O que é preciso ressaltar aqui é o caráter problemático envolvido nessa questão. Lacan reconhece esse aspecto ao falar do assunto no Seminário 1: "Desde que este ponto foi colocado (..) muitas coisas se orientam e se esclarecem, mas muitos paradoxos e contradiçóes aparecem." (1953-1954/1975, p. 126). A seu ver, o mérito desse esforço conceitual foi exatamente fazer aparecerem esses paradoxos e essas contradições. Um desses problemas é indicado no fato de o método analítico visar atingir a fala plena ao mesmo tempo em que parte de uma via que é oposta a ela: a associação livre, já que esta "(...) dá como consigna ao sujeito delinear uma fala tão desligada quanto possível de

7 Contra essa afirmação de Macey, existe o fato de Lacan ter voltado a recorrer à oposição fala vazia/fala plena durante o seminário de 1976-1977, no qual relacionou a primeira à significação e a segunda à dimensão do sentido (Evans, 1996). 
toda suposição de responsabilidade, e que o libera mesmo de toda exigência de autenticidade.”(Lacan, 1953-1954/1975, p. 126). Paradoxo talvez mais aparente do que real pois, em termos freudianos, embora se saiba que a expressão "associação livre" contenha mesmo algo de inadequado frente à escolha determinista de Freud, seu "livre" significa apenas que é justamente na tentativa de eliminar a censura do sistema pré-consciente/consciente, ou seja, de suprimir a seleção voluntária dos pensamentos, que se abre espaço para a revelação de materiais inconscientes (que não são, no entanto, indeterminados) e, portanto, da "autenticidade" do desejo do sujeito que constitui a fala plena (Laplanche \& Pontalis, 1967/1992).

Outros problemas relacionados à oposição fala vazia/ fala plena poderiam ser mencionados. Tal como trabalhado na seção IV do Seminário 1, o tema se liga às questões da transferência e da resistência de forma que, grosso modo, por um lado, fala vazia significa resistência, fala que, por se esquivar do inconsciente, ao invés de se centrar na função da revelação, liga-se à mediação; o sujeito se prende ao hic et nunc com o analista e se perde no sistema da linguagem. Como afirma Lacan: “(...) é na medida em que a confissão do ser não chega ao seu termo, que a fala se lança inteiramente na vertente em que ela se agarra ao outro." (1953-1954/1975, p. 59). Ou:

A resistência se produz no momento em que a fala de revelação não se diz, em que (...) o sujeito não tem mais saída. Ele se agarra ao outro porque aquilo que é impelido em direção à fala não acedeu a ela. (...) Se a fala funciona então como mediação, é por não se ter realizado como revelação. (1953$1954 / 1975$, p. $59 / 60)$.

Por outro lado, fala plena significa aproximação da verdade do desejo e, portanto, substitui a mediação pela revelação. Disso se deduz, então, uma conclusão provavelmente insustentável: que a transferência, função da mediação - pois é aí que o sujeito se dirige mais intensamente ao outro - surge com a resistência, com a fala vazia. Mas, como pode a transferência - que apesar de sua face voltada para a resistência é o principal motor da análise, a especificidade maior do processo analítico, sem a qual nada se passa - estar ligada à fala vazia e não à fala plena? Assim, transferência, resistência, fala plena, fala vazia, revelação e mediação encontram-se envolvidas em interrelações ao menos aparentemente contraditórias. Talvez esse nó mesmo tenha sido a motivação inicial para o desenvolvimento subseqüente da diferenciação entre transferência imaginária - algo a ser superado, pois impede o desenrolar do processo analítico, funcionando como resistência - e transferência simbólica - essa sim, o instrumento da psicanálise, indicando o campo do significante como seu espaço de trabalho. Lacan identificou um aspecto desse paradoxo da seguinte forma:

(...) vejam o paradoxo da posição do analista. É no momento em que a palavra do sujeito é a mais plena, que eu, analista, poderia intervir. (...) Ora, quanto mais o discurso é íntimo para o sujeito, mais eu me centro nesse discurso. Mas o inverso é igualmente verdadeiro. Quanto mais o seu discurso é vazio, mais sou levado, também eu, a me agarrar ao outro (...). (19531954/1975, p. 61).
E estipulou que a forma de sair desse círculo vicioso da relação com o outro é ser capaz de ultrapassar o registro do imaginário, entender que quanto mais o sujeito se afirmar como eu, mais ele se enredará na alienação, e buscar uma resposta para a seguinte pergunta: “(...) quem é então aquele que, para além do eu, procura fazer-se reconhecer?” (Lacan, 1953-1954/1975, p. 62).

Outro problema que pode ser identificado nesse assunto é que, de uma parte, como afirma Macey (1988), na fala vazia, o sujeito, ao invés de falar, é falado pela linguagem, é inautêntico, alienado, despossuído e, de outra, a fala plena é relacionada com a verdade do sujeito inconsciente. Ocorre que, mais tarde na obra de Lacan, o sujeito "verdadeiro", o sujeito do inconsciente, será justamente algo falado pela linguagem, determinado pelo significante. Sobretudo, a noção de fala vazia não pode conviver com a idéia do primado do significante, pois todo e qualquer discurso revela o sujeito do inconsciente. Não será preciso estar falando de assuntos íntimos, da própria história, para que o sujeito esteja aí implicado. Existem, aliás, passagens no próprio Discurso que apontam, de certa forma, o reconhecimento dessa inconsistência. Por exemplo, quando Lacan afirma que um discurso qualquer, mesmo quando parece ser vazio de sentido, revela o sentido do exercício de sua função. Assim, diz o autor: “(...) a fala, mesmo no extremo de sua usura, guarda seu valor de téssera" (1953b/1966, p. 251) e "Mesmo se não comunica nada, o discurso representa a existência da comunicação (...).” (1953b/1966, p. 251). Em vista disso, como pode haver uma fala vazia? De dentro mesmo do referencial lacaniano, é possível afirmar que um discurso, mesmo que tente se prender à ilusão narcísica, não pode deixar de apontar para o fato simbólico de sua própria existência.

\section{Intersubjetividade}

A essência de intersubjetividade e de interlocução da análise constitui as funções de locutor e ouvinte nela envolvidas e estabelece a continuidade do discurso no qual se desenrola a história do sujeito. A intersubjetividade efetivada pela função simbolizadora da fala transforma a condição do receptor da mensagem, que a partir daí tem acrescentada em seu mundo, a realidade de uma relação com o emissor. A mais importante função da fala é, portanto, implicar “(...) seu autor ao investir seu destinatário de uma nova realidade (...)" (Lacan, 1953b/1966, p. 298), como por exemplo, quando um cônjuge diz ao outro "Tu és minha mulher" . Esse ato que cria para o outro uma nova realidade é, segundo Lacan, a forma essencial da fala. Aí, sua simples expressão é capaz de definir a subjetividade alheia. Nessa forma essencial reside o poder original do significante, a faculdade que ele possui de implicar de imediato a resposta que lhe cabe - pois todo discurso já traz em suas lacunas um sentido inconsciente - e de determinar a realidade e o sujeito. $\mathrm{O}$ valor da fala não está, então, na informação objetiva que transmite, mas na reverberação do discurso do outro que constitui a fala plena. Assim, o que é redundância no nível da informação funciona como ressonância no nível do inconsciente, o que

8 Fazendo uso da noção de "performatório" desenvolvida por John Langshaw Austin. 
é funcional para a linguagem, é irrelevante para a fala. $\mathrm{Na}$ fala, o que importa é o ato de endereçamento ao outro. "Pois, nela, a função da linguagem não é informar, mas evocar.” (Lacan, 1953b/1966, p. 299). Falar é sobretudo requisitar a resposta do outro, provocá-lo por um nome que ele assume ou recusa.

Lacan relata que certa vez foi-lhe colocado, a título de objeção, que seus ensinamentos enunciavam o paradoxo de que a linguagem seria “(...) uma comunicação em que o emissor recebe do receptor sua própria mensagem sob forma invertida (...).” (Lacan, 1953b/1966, p. 298). Para o autor, a crítica só contribui para expressar melhor o que ele queria mesmo dizer, pois quando o analista responde ao discurso do sujeito é para lhe sublinhar a parte avessa, ou seja, para destacar em sua fala plena, o movimento da verdade do desejo inconsciente. Isso significa reconhecer a subjetividade do paciente, ou seja, produzir nele uma transformação efetiva. A outra alternativa para o analista é abolir o paciente como sujeito, afastá-lo do conhecimento de sua própria realidade, o que Lacan vê ocorrer nas correntes psicanalíticas em vigor naquela época. Reconhecer o sujeito é indicar sua implicação em seu próprio desejo e promover a enunciação da fala plena. Aboli-lo é fomentar a manutenção de sua alienação, de sua identificação objetivante na fala vazia.

Quando a continuidade do discurso do analisando é interrompida, revela-se o inconsciente como terceiro termo da situação. Ele não é uma individualidade pulsional recôndita, mas um elemento do discurso concreto transindividual: " $O$ inconsciente é essa parte do discurso concreto, enquanto transindividual, que falta à disposição do sujeito para restabelecer a continuidade de seu discurso consciente." (Lacan, 1953b/1966, p. 258). Com essa leitura do fenômeno, Lacan entende ter superado o paradoxo que ele vê residir na noção de inconsciente quando relacionada com uma realidade individual, questão que remonta ao problema da expressão "representação inconsciente". Aqui, ele diz que Freud, ao usar a expressão "pensamento inconsciente" conjuga termos contrários e tanto o saberia que, no caso do Homem dos Lobos, desculpou-se por isso com um sit venia verbo. Que não são contrários nos limites do psiquismo individual é justamente a tese que Freud procurou defender com sua obra. Mas o importante para esse momento é sublinhar que, nessa passagem, Lacan confirma sua movimentação em torno do conceito de inconsciente, que só agora, ao haver-lhe encontrado uma leitura intersubjetiva, distante da realidade biológica individual, pode designar para esse conceito um lugar num pensamento que desde a origem já recusava o recurso à biologia9. A expressão "pensamento inconsciente" deixa de ser contraditória porque a realidade do discurso é transindividual. O objeto da psicanálise, para Lacan, não é uma realidade individual, mas a realidade intersubjetiva concreta e autônoma do discurso. Daí a famosa declaração “o inconsciente é o discurso do outro" (Lacan, 1953b/1966, p. 265). Logo, o inconsciente, apesar de não remeter à miragem de uma coletividade, é uma estrutura simultaneamente singular, porque determina a urdidura subjetiva do desejo e, social, porque sinônima, em última instância da estrutura

9 Na década de 40, o inconsciente era rechaçado como noção "inerte e impensável” (Lacan, 1946/1966, p. 182). do discurso humano em geral, pois sua subsistência como sistema de operações é conseqüência direta da relação humana com a linguagem, é expressão de sua faculdade para a simbolização. Assim, a verdade mais íntima é também uma verdade universal. Lacan encontra no mote hegeliano da identidade do particular e do universal mais um gancho para desenvolver essa idéia. Diz que a psicanálise forneceu o paradigma dessa exigência já que a linguagem do sujeito em análise remete tanto a um simbolismo universal quanto à articulação significante singular de seu próprio desejo. Assim, o indivíduo não pode consistir numa totalidade. A idéia de que o homem seja um ser inteiro, completo, indivisível não passa de uma ilusão, pois o que ele exprime com seu ser é uma condição de divisão devida a esse sujeito que, à sua revelia, revela em seu corpo, em seu comportamento, em sua fala, em sua vida, enfim, a construção de sentido resultante da função humana universal da comunicação.

A dualidade implicada nas relações imaginárias, na operação de identificação com uma imagem, é, a partir de então - mediante o movimento que incorpora o conceito de inconsciente à doutrina e que afasta Lacan de suas pretensões de construir uma psicologia - suplementada pela referência ao registro simbólico, aquele que abriga a autenticidade do desejo e do sujeito.

O lugar em que o inconsciente se manifesta são as descontinuidades desse discurso transubjetivo: "O inconsciente é $O$ capítulo de minha história que é marcado por um branco ou ocupado por uma mentira: é o capítulo censurado." (Lacan, 1953b/1966, p. 259). O sentido dessas descontinuidades pode ser recuperado por meio de uma exegese porque a verdade nelas contida não deixa de ganhar inscrição em lugares (todos apontados por Freud) como o corpo - no qual o sintoma revela possuir "a estrutura de uma linguagem" (Lacan, 1953b/1966, p. 259) -, as lembranças da infância, o vocabulário, o estilo de vida, as tradições e lendas, as distorções do discurso consciente, etc. Para indicar esses lugares, Lacan se vale de metáforas como "monumentos" para significar o corpo ou "documentos de arquivo" para indicar as lembranças da infância e afirma que, numa análise, elas perdem sua dimensão metafórica porque é na metáfora mesma que age o analista, ou seja, ele não recorre à metáfora para alcançar algo que estaria além dela, além da fala e do próprio registro simbólico. Essa metáfora sobre a qual atua o analista é o mesmo que a operação da formação do sintoma que se dá também por deslocamento simbólico. Do nascimento do sintoma, alvo do tratamento analítico, ao registro de atuação do psicanalista, passando pelo estofo do conceito central de inconsciente, a psicanálise é toda recoberta e definida por sua identidade com a ordem simbólica, com o campo da linguagem.

\section{Significante e ordem simbólica}

Que a linguagem é a lei não só do inconsciente, mas do próprio homem, é então a bandeira do projeto lacaniano relativo à década de 50. "Reconhecimento" e "dádiva" serão as palavras-chave a indicarem o sentido em que esse lema é empunhado. No primeiro, reside todo o desdobramento dos temas dialéticos que têm na figura de Kojève seu emblema e dos temas fenomenológicos oriundos especialmente da leitura de Heidegger. No segundo, reverberam os ensinamentos 
da antropologia estruturalista. As leituras de cada uma dessas matrizes não adquirem significado separadamente, mas, ao contrário, se interconectam de modo bastante íntimo, chegando, às vezes, a se manifestarem em um mesmo golpe do pensamento. É o caso, por exemplo, da reflexão a respeito do livro Do Kamo: a pessoa e o mito no mundo melanésio, de Maurice Leenhardt. Aí, Lacan pretende ter encontrado elementos para confirmar que “(...) a lei do homem é a lei da linguagem, desde que as primeiras palavras de reconhecimento presidiram as primeiras dádivas (...).” (Lacan, 1953b/1966, p. 272). Para ele, essa pesquisa antropológica, ao mostrar que, para os "pacíficos Argonautas" (expressão que remete ao estudo de Malinowski e que aqui substitui, obviamente, os melanésios), a mesma palavra utilizada para designar "fala" servia igualmente para designar as dádivas, o ato de doar, os objetos doados, a fabricação desses objetos e a instituição das dádivas como signos, confirma a veracidade da relação de identidade entre reconhecimento, dádivas e palavras.

Lacan, seguindo a temática levantada na obra de Marcel Mauss pelos termos mana e hau, coloca que essas dádivas são em si mesmas, símbolos, pois, tal como indica a etimologia que remete à téssera, os símbolos são “(...) significantes do pacto que constituem como significado (...)” (Lacan, 1953b/1966, p. 272). As dádivas são símbolos, não do objeto doado numa relação representativa fixa com um significado inconsciente - e é por isso que esses objetos são sempre supérfluos, abundantes, alheios a qualquer intenção pragmática -, mas da própria troca simbólica, ato que funda a condição coletiva da humanidade que, de outra forma, não poderia existir. Para o autor, a troca simbólica das dádivas na neutralização do significante - isto é, em sua separação do significado - representa a existência da linguagem como lei do homem. Em consonância com a racionalidade estruturalista, ele vê nisso a verdadeira essência da linguagem, ou seja, no fato de que o significante remete não ao significado, mas a um sistema inconsciente de trocas simbólicas, ao ato necessário da permutação. Assim, se Lacan prefere o "no início era o verbo" de São João ao "no início era o ato" de Goethe (que, por sua vez, era preferido por Freud), é preciso lembrar que esse verbo já é em si ato. Aliás, o ato humano por excelência porque a fala, ao instituir um pacto, consiste no ato simbólico do reconhecimento e do estabelecimento de uma ordem de existência.

Relatando a lição aprendida dos prospectos de lingüística estruturalista, Lacan anuncia sua compreensão do significante: "(...) o que define como pertencente à linguagem um elemento qualquer de uma língua é que ele se distingue como tal, para todos os usuários dessa língua, no suposto conjunto constituído pelos elementos homólogos." (1953b/1966, p. 274). O que importa na consideração do significante não é que ele se relacione com um significado, mas que seu lugar seja referenciado ao conjunto dos outros significantes que compõem a língua. Esse conjunto de elementos é a estrutura da língua à qual se devem os efeitos de linguagem que são as formações do inconsciente. A via que liga tal estrutura à experiência subjetiva é de mão única: seu tráfego parte sempre da primeira para chegar à segunda e nunca o contrário. Em outras palavras, o sujeito é, de ponta a ponta, um fenômeno de linguagem como tal inteiramente submetido ao determinismo da ordem simbólica. Lacan insurge-se, assim, contra a idéia de que a linguagem seria constituída por relações fixas de representação, ou melhor, poderíamos dizer, contra a inserção do conceito de representação na teorização da linguagem, fazendo, com isso, coro a um refrão tipicamente estruturalista. $\mathrm{O}$ significante (ou o signo porque nesse momento esses termos não parecem ser usados segundo especificações teóricas ${ }^{10}$ ) não expressa a realidade. Em última instância, ele é símbolo apenas da própria comunicação.

As origens do comportamento simbólico podem ser procuradas fora do domínio humano. Por exemplo, as gaivotas, em sua espontaneidade, realizam "festas" em que um peixe, que aí funciona como símbolo, é passado de bico em bico. No entanto, um objeto simbólico não é suficiente para constituir a lei e a linguagem. Lacan estipula que mesmo que houvesse exploração de um animal pelo outro isso não bastaria para que um universo específico emergisse. Continuaria faltando o "algo" que precisa completar o símbolo para a constituição da linguagem e o nascimento da história. Esse algo é palavra. Assim, a dialética do senhor e do escravo precisa chegar ao ponto máximo de abstração para que um universo humano encontre suas possibilidades. No ser evanescente da palavra que se desloca das relações diretas com a atualidade, o objeto simbólico descobre o conceito: "Para que o objeto simbólico, liberto de seu uso, transforme-se na palavra libertada do hic et nunc, a diferença não é a qualidade, sonora, de sua matéria, mas seu ser evanescente, onde o símbolo encontra a permanência do conceito." (Lacan, 1953b/1966, p. 276). A palavra é a presença de uma ausência; indica, por sua existência, a falta do objeto e, com isso, engendra o conceito que é a própria coisa. Só na palavra a coisa existe concretamente (ao mesmo tempo em que deixa de existir). Assim, se o conceito é a coisa e é a palavra que gera o conceito, então, "É o mundo das palavras que cria o mundo das coisas, inicialmente confundidas no hic et nunc do todo em devir (...)." (Lacan, 1953b/1966, p. 276).

Mas, poderíamos então questionar, se Lacan costuma, como se sabe, privilegiar radicalmente o significante em detrimento do significado, por que parece aqui ater-se ao conceito, algo mais próximo, à primeira vista, do significado? É que a idéia de conceito - que provém do pensamento hegeliano - mediante uma manobra que atravessa num mesmo gesto a filosofia de Heidegger, o estruturalismo e a análise freudiana do Fort-da, aparentemente passa a ser sinônima da palavra, ou seja, do significante, que aponta inexoravelmente para a finitude da existência humana. Nesse ponto, Lacan segue o desenvolvimento de uma equação lógica: se o idealismo absoluto identifica o real ao conceito e a operação intelectual em jogo consiste em identificar conceito a palavra, então, torna-se possível ter como conclusão que a própria palavra seja idêntica ao real. O objetivo desse movimento consiste exatamente em deslocar a linguagem de um pólo atrelado ao significado para um outro que busca confirmar sua essência

10 Posteriormente, com o desenvolvimento da reflexão que aqui se esboça Lacan vai passar a defender a primazia do significante e este será durante bastante tempo um dos principais conceitos de seu arsenal teórico, relegando a escanteio o significado e substituindo o lugar que o conceito de signo ocupava no pensamento de Saussure ou no de Lévi-Strauss (Wilden, 1968). 
metafórica. Tendo esse deslocamento em vista, o autor retorna, então, à análise do fenômeno do Fort-da, que já fora objeto de reflexão no artigo sobre a família de 1938, enriquecendo-o com outros conceitos e com outras idéias. Existe aí um cruzamento de matrizes conceituais que o autor faz explodir num procedimento que é característico desse texto. O jogo simbólico infantil analisado por Freud é pensado como paradigma do momento original, de nascimento da fala sobre a falta, em que a palavra se revela como a presença de uma ausência, ou seja, a palavra torna a coisa presente por significar a ausência dessa coisa mesma. O objeto tem, então, sua realidade destruída no processo de simbolização que gesta o desejo e a dialética, própria à existência humana, entre presença e ausência, símbolo e coisa, eu e outro, identidade e diferença, etc: “(...) o símbolo se manifesta inicialmente como assassinato da coisa, e essa morte constitui no sujeito a eternização de seu desejo.” (Lacan, 1953b/1966, p. 319). No instante em que a criança nomeia a oposição presença/ausência da mãe por uma oposição fonética, nasce, de uma só vez, todo o universo de sentido da linguagem que se sobrepõe ao universo das coisas. Tal como no artigo sobre a família, há, nessa nova interpretação do Fort-da, a forte presença do mote hegeliano. Lembremos: em 1938, o Fort-da era entendido, a partir da questão da dominação e da dialética do senhor e do escravo, como o momento em que a criança reencenava seu mal-estar para exercer sobre ele alguma espécie de domínio e, assim, superar sua condição que era de estrita passividade. Só que agora outro motivo hegeliano também é valorizado: a dialética entre palavra e coisa ou entre palavra e conceito. Essa mudança de estratégia é devida ao fato de que, no Discurso, os motivos hegelianos devem se encaixar num diálogo com os temas disponibilizados pelo estruturalismo e também pela filosofia de Heidegger. Lacan parece elaborar explicitamente esse enriquecimento de sua interpretação no trecho a seguir:

Podemos agora discernir que o sujeito não domina aí apenas sua privação, assumindo-a [essa era a explicação fornecida em 1938], mas que eleva seu desejo a uma potência secundária. Pois sua ação destrói o objeto que ela faz aparecer e desaparecer na provocação antecipatória de sua ausência e sua presença. Ela negativiza assim o campo de forças do desejo, para se tornar, em si mesma, seu próprio objeto. (1953b/1966, p. 319).

Essa elevação do desejo à segunda potência significa, então, que ao passar para a linguagem, o objeto deixa de existir em sua realidade específica e a ação, pela repetição do jogo, torna essa ausência presente, transformando-se ela mesma, por esse movimento, no novo objeto do desejo. Assim, o Fort-da é agora paradigmático de toda condição de fala. Se, como afirma a lingüística estrutural, toda língua é composta de um conjunto de oposições binárias de fonemas, o Fort-da constitui exatamente uma dessas oposições. Esse instante em que a criança procura controlar a ausência da mãe é o momento do nascimento do símbolo e também a ocasião em que o desejo se torna humano. Desde esse ponto, a criança sofre não mais de uma necessidade, mas de uma falta a ser. Acede à condição de "derrelição" - presumivelmente, segundo Muller e Richardson (1982), a tradução de
Lacan para o termo Geworfenheit de Heidegger - estado de abandono, de desamparo que é constitutivo do ser humano. Ela percebe a radical alteridade da mãe e deseja ser o objeto de seu desejo, ser reconhecida por ela ou, segundo o lema kojèviano, seu desejo é desejo do desejo do outro e não de um objeto. Nos símbolos Fort e da, o desejo da criança é fragmentado e articulado segundo a comunidade lingüística em que ela vive ${ }^{11}$. Em outras palavras, a estrutura da linguagem, como discurso do outro, determina os caminhos da fala.

Essa discussão sobre o assassinato da coisa, que é a morte do sujeito, encabeçada pelo Fort-da intenciona mostrar a relação entre a faculdade da fala e o instinto de morte, o que conduz à afirmação de que este não é um conceito biológico. Para Lacan, é importante entender seu verdadeiro sentido porque esta é uma noção fundamental para a realização de uma leitura adequada do sentido dialético da obra de Freud; ela é a “(...) primeira via de acesso para penetrar em seu sentido e dimensão essencial para compreender sua repercussão dialética (...).” (Lacan, 1953b/1966, p. 317). É preciso, mais uma vez, superar os possíveis laços que a obra freudiana ainda pudesse esboçar com o campo da biologia e, em razão disso, indicar a direção que deve tomar uma correta interpretação da função da morte em psicanálise. A repetição envolvida na operação simbólica do Fort-da não é representativa de um masoquismo primordial, como o queria Freud, mas da experiência da condição de finitude que a criança vive em sua separação da mãe. Aí, ela experimenta a limitação de sua própria realidade. O que se faz presente no que Freud chamou de compulsão à repetição e que Lacan, em dívida com Clérambault (Macey, 1988), traduz por "automatismo de repetição" é, para este, a historicidade como condição primeira da experiência humana no sentido do "ser-para-a-morte" descrito por Heidegger. No texto sobre os complexos familiares (Lacan, 1938), a gênese desses fenômenos de morte e de repetição era reputada ao trauma do desmame e à sua sublimação malsucedida, ao processo de identificação com o outro e à experiência do corpo despedaçado. Encontrava-se aí igualmente relacionado a uma análise do Fort-da. No Discurso, essa reflexão ganha uma extensão bem maior e a morte é investida com tanta abstração que se tornam evidentes seus ares metafísicos. Ela é, então, o signo maior dessa primeira experiência de linguagem, tanto em função da primeira experimentação que tem a criança de sua própria finitude, quanto em razão do assassinato da coisa exigido pelo uso da simbolização na fala. Encontrase implacavelmente implicada na ordem simbólica: “(...) quando queremos atingir no sujeito o que havia antes dos jogos seriais da fala, vamos encontrá-lo na morte, de onde sua existência retira tudo o que tem de sentido." (Lacan, 1953b/1966, p. 320). Tal leitura parece ser fundada muito mais na filosofia heideggereana do "ser-para-a-morte" do que nos textos freudianos ou no próprio exercício da clínica. É a partir da estrutura ontológica-existencial do Dasein e não da pulsão que, na presente visão de Lacan, devem ser compreendidas a morte e a repetição na psicanálise. Numa palavra, o Fort-da é emblemático da interrelação e da concomitância

11 Mais tarde, essa articulação será denominada "cadeia significante". 
que Lacan vê existirem entre a experiência humana da morte, a fundação do desejo e o nascimento da linguagem.

Pelo que vimos acima, no pensamento lacaniano desse período, a ordem simbólica é a instância última de determinação tanto do mundo (o mundo das palavras cria o mundo das coisas) quanto do sujeito (o acesso à linguagem humaniza o desejo: "O homem fala, pois, mas porque o símbolo o fez homem." (Lacan, 1953b/1966, p. 276)). Para fundamentar melhor essa segunda parte da tese, Lacan recorre a As estruturas elementares do parentesco, reafirmando as teses básicas de Lévi-Strauss. Esse autor, cuja influência foi decisiva para a articulação entre o inconsciente psicanalítico e as leis da linguagem, discorre sobre a submissão inconsciente da vida em comunidade à estrutura do parentesco, a qual possui a mesma forma da submissão do homem às leis da linguagem. Nessa estrutura, em que Lévi-Strauss vê a regulação de todas as operações de troca, existe uma lógica combinatória, matemática, que é sinônima da ordem simbólica, ou seja, que é sinônima do inconsciente.

A lógica da ordem inconsciente das estruturas de parentesco e a proibição do incesto aí implicada traduzem-se, no terreno da psicanálise, no conceito de complexo de Édipo. Este não é um acontecimento psicológico determinado pela configuração familiar burguesa, mas um fenômeno humano universal conseqüente à relação entre a estrutura inconsciente da aliança e da linguagem e a proibição do incesto como fato cultural primordial. Ao contrário do que ocorria no artigo sobre os complexos familiares, no qual um certo privilégio teórico era concedido ao complexo de intrusão, a partir dessa aproximação com a racionalidade estruturalista, é o complexo de Édipo que prevalece. Lacan afirma que ele recobre todo o sentido da psicanálise. Determinante para essa mudança é a aproximação providenciada por Lévi-Strauss entre interdição do incesto e ordem simbólica, entre lei e linguagem. Em função exatamente desses termos é que o complexo de Édipo será reinterpretado por Lacan e é por isso que ele agora assume essa centralidade. De fato, ele é o nó capaz de unir os temas psicanalíticos à antropologia estrutural e de resumir a presente proposta de Lacan, que é a de ler a psicanálise a partir da linguagem.

O homem é inconsciente do funcionamento da estrutura simbólica e por isso crê na liberdade de suas escolhas. Não sabe que, na verdade, essas escolhas são determinadas por uma lei primordial que, sobrepondo-se à natureza, funda o reino da cultura, garantindo a continuidade do ciclo das trocas de dádivas, palavras e mulheres, segundo a tríade lévi-straussiana. É a ordem simbólica com sua causalidade estrutural que produz as relações entre os sujeitos, seus sintomas, seus sonhos e suas angústias, suas histórias, enfim. Os símbolos envolvem o homem numa rede total e determinam seu destino. Lacan encontra nessa reflexão os elementos para redescrever a psicanálise e formular a tese fundamental desse texto que é também a tese fundamental de todo o seu projeto relativo a essa época. Que Lévi-Strauss tenha sido efetivamente o guia desse seu percurso, é o próprio autor quem o revela: "Não é patente que um Lévi-Strauss, ao sugerir a implicação das estruturas da linguagem e da parte das leis sociais que rege a aliança e o parentesco, já conquista o terreno mesmo em que Freud assenta o inconsciente?" (Lacan, 1953b/1966, p. 285).
Sob o crivo do estruturalismo, a psicanálise deve, então, procurar assegurar para si a legitimidade de um lugar na ciência moderna. Segundo Lacan, ela sempre havia procurado obter esse lugar mediante um viés equivocado que era o das relações com o saber médico e com o método experimental. A seu ver, o caminho para essa realização é, na verdade, o da formalização. A função simbólica, por meio do trabalho da antropologia estrutural, instaura uma nova ordem científica e o psicanalista é capaz de se encontrar aí porque sua tarefa consiste exatamente em praticar essa função. Nisso, o papel da lingüística estrutural é de extrema importância, tanto porque revelou para a antropologia a possibilidade do rigor quanto, e principalmente, porque inaugurou um retorno à verdadeira ciência na qual as ciências humanas não são mais subordinadas às ciências experimentais, superando a era positivista.

É preciso, portanto, instrumentalizar a psicanálise com a lingüística da mesma forma que o fez a antropologia estrutural e, a partir de uma teoria geral do símbolo, configurar um novo quadro para as ciências no qual tenham lugar central as ciências da subjetividade. Essas, que Lacan nomeia "conjecturais", não são menos consistentes do que as ciências exatas, "Pois a exatidão se distingue da verdade e a conjectura não exclui o rigor." (Lacan, 1953b/1966, p. 286).

Nem mais imago, como a promessa de cientificidade, nem psicologia, como disciplina a ser construída (como ocorria com a teoria do imaginário), mas a linguagem e o corpo teórico da psicanálise como vigas de um novo projeto que, no entanto, não abandona os princípios do anterior. Princípios que Lacan sempre considerou como os únicos possíveis aliados na construção de uma ciência do sujeito: anti-realismo, anti-individualismo e anti-biologismo. Só não permanece aí a fidelidade a uma postura anti-reducionista, da qual Lacan parece ter desistido ao reduzir a explicação de todos os fenômenos humanos ao funcionamento da ordem simbólica.

\section{Considerações Finais}

A preconização de um "retorno a Freud" significa sobretudo as boas-vindas ao conceito de inconsciente que, somente agora, após receber uma vestimenta estruturalista, se depara com novas condições de possibilidade capazes de satisfazer os princípios do percurso teórico de Lacan. Resgatar a força técnica da psicanálise - que, para o autor, encontrava-se em decadência - e encaminhá-la rumo a um caráter científico, desde sempre problemático, são tarefas realizáveis somente mediante a retomada da leitura da obra freudiana. Aos olhos de Lacan, a única via possível para esse retorno ao sentido da experiência psicanalítica é investir a leitura de Freud com o poder teórico e prático do trabalho com a linguagem.

O Discurso de Roma revela, enfim, um programa em que muito do que é assunto pertinente à psicanálise - desejo, inconsciente, sintoma, édipo - acha-se redefinido a partir de novos instrumentais que se cruzam e se fecundam reciprocamente. Entre eles, entendemos que a grade estruturalista ocupa lugar central, pois foi ao se aproximar dela que Lacan pôde finalmente enveredar de vez para a psicanálise e reclamar para si a realização de um retorno a Freud, que a seu ver permitiria a essa disciplina ter finalmente garantido 
o seu lugar no domínio científico. A idéia que se deseja transmitir é a de que basta ler os textos freudianos e a justa conclusão que daí decorre é que o território do inconsciente é totalmente delimitado pela função da fala e pelo campo da linguagem. Dadas as outras influências, essa leitura de cunho estruturalista já nasce matizada de forma que fala e linguagem acham-se acompanhadas da história, na função de delimitar todo o terreno da psicanálise.

\section{Referências}

Barthes, R. (1993). Elementos de semiologia. São Paulo: Cultrix (Originalmente publicado em 1964).

Evans, D. (1996). An introductory dictionary of lacanian psychoanalysis. Londres e Nova York: Routledge.

Lacan, J. (1938). La famille. Em Encyclopédie Française. Paris: Larousse.

Lacan, J. (1945). Le temps logique et l'assertion de la certitude antécipé. Em J. Lacan (1966). Écrits (pp. 197-203). Paris: Seuil.

Lacan, J. (1946). Propos sur la causalité psychique. Em J. Lacan (1966). Écrits (pp. 151-193). Paris: Seuil.
Lacan, J. (1951). Intervention sur le transfert. Em J. Lacan (1966). Écrits (pp. 215-226). Paris: Seuil.

Lacan, J. (1953a). Le mythe individuel du nevrosé. Ornicar? 17-18, 1978 (pp. 290-307). Paris: Lyse

Lacan, J. (1953b). Fonction et champ de la parole et du langage en psychanalyse. Em J. Lacan (1966). Écrits (pp. 237-322). Paris: Seuil.

Lacan, J. (1966). Du sujet enfin en question. Em J. Lacan (1966). Écrits (pp. 229-236). Paris: Seuil.

Lacan, J. (1975). Le Séminaire. Livre I: Les éscrits techniques de Freud (1953-1954). Paris: Seuil.

Laplanche, J. \& Pontalis, J.-B. (1992). Vocabulário da Psicanálise. São Paulo: Martins Fontes (Originalmente publicado em 1967).

Macey, D. (1988). Lacan in contexts. Londres, Nova York: Verso.

Müller, J. \& Richardson, W. (1982). Lacan and language. A reader's guide to Écrits. Nova York: International Universities Press.

Wilden, A. (1968). Lacan and the discourse of the other. Em J. Lacan (Org.). Speech and language in psychoanalysis. Baltimore and Londres: The Johns Hopkins University Press.

Recebido em 26.08.2003

Primeira decisão editorial em 15.01.2004

Versão final em 26.02.2004

Aceito em 23.03.2004 